\title{
Learning to lead
}

\section{It's not just in classrooms anymore!}

\author{
by Raynna Bowlby
}

$\mathrm{L}$ eaders are perpetual learners ... [Learningl is absolutely indispensable under today's conditions of rapid change and complexity . . . Leaders have discovered not just how to learn but how to learn in an organizational context. They are able to concentrate on what matters most to the organization and to use the organization as a learning environment."

ACRL President Maureen Sullivan's theme of "Leadership and Learning" catches none of us by surprise. Indeed, the "L words" are constantly on the lips of many in our libraries. Yet, they are spoken with the hint of mystery and awe. Just what is leadership anyway? And, even for the many of us who work in institutions of higher education, just what is learning these days? And, seemingly most mysterious of all, how does one learn to lead?

\section{Are you born with it?}

Warren Bennis and Burt Nanus remind us through their work that our view of what leadership is and who exercises it has changed over the centuries. Explanations have shifted from the "Great Man" theory that leaders are born, not made, to the "Big Bang" theory that great events make leaders of otherwise ordinary people.

Current belief is based to a great extent on the work of James MacGregor Burns and Bernard M. Bass on the "Transformative Leadership" theory, that is the transformational leader is one who motivates others to do more than they originally expected to do. Bennis and Nanus maintain that "effective leadership can move organizations from current to future states, create visions of potential opportunities for organizations, instill within employees commitment to change and instill new cultures and strategies in organizations that mobilize and focus energy and resources. These leaders are not born. They emerge when organizations face new problems and complexities that cannot be solved by unguided evolution. They assume responsibilities for reshaping organizational practices to adapt to environmental changes. They direct organizational changes that build confidence and empower their employees to seek new ways of doing things. They overcome resistance to change by creating visions of the future that evoke confidence in and mastery of new organizational practices."

\section{Learning to lead}

If leaders, then, are not born, what is critical is learning to lead. Peter Vaill proposes "learning as a way of being" for "survival in a world of permanent white water," that is, the unpredictable environment of constant change. ${ }^{3}$ According to Vaill's innovative philosophy of learning, just as white water continuously puts people in challenging situations that they have never encountered or experienced, learning how to successfully navigate constant change cannot be left to formal, insti-

\section{About the author}

Raynna Bowlby is Organizational \& Staff Development officer of the Brown University Library and a member of the ACRL President's Program Committee, e-mail: raynna_bowlby@brown.edu 
tutional training and degree programs, rather integrating the discipline of learning into everyday practice is necessary. Vaill describes this learning as multi-faceted and he defines seven types of learning-self-directed, creative, expressive, feeling, online, continual, and reflexive learning.

Another important dimension of learning, action learning, is increasingly being applied in modern organizations. Initially pioneered by $\mathrm{R}$. W. Revans, action learning involves taking action in "real time," learning from the results, and incorporating that learning into future action using the organization itself as the learning context.

This is a new mental model for learning, differing from our traditional learning model in many ways. It is work-based rather than classroom-based, has a group orientation rather than an individual orientation, focuses on output rather than input, is active rather than passive, is concerned with the present and future rather than the past, deals with reality rather than hypothetical situations.

Action learning abounds in our academic and research libraries today, though we may not label it as such. For example, participation in library-wide strategic planning initiatives and development of self-managed teams are significant action learning opportunities. Through these activities we are learning by doing and at the same time "emerging" as leaders, recalling Bennis and Nanus' description above. As we all engage in this new work, we not only develop ourselves but we also lead the learning process in our organizations.

"Organizational learning is the process by which an organization obtains and uses new knowledge, tools, behaviors, and values. It happens at all levels in the organizationamong individuals and groups as well as systemwide. Individuals learn as part of their daily activities, particularly as they interact with each other and the outside world. Groups learn as their members cooperate to accomplish common goals. The entire system learns as it obtains feedback from the environment and anticipates further changes. At all levels, newly learned knowledge is translated into new goals, procedures, expectations, role structures, and measures of success." ${ }^{m 4}$

(continued on page 318)

\section{$\mathrm{G} \cdot \mathrm{K} \cdot$ Hall $\&$ C?}

NEW! WEMEN ARTISTS

\section{QN DISC}

Compiled by G.K. Hall \& Co.

First Edition of a New Art History Resounce

Women Artists on Disc is the most comprehensive bibliography of women artists available and an authoritative resource to wide-ranging reference materials on women's art history in the Western World. It consolidates key feminist and traditional scholarship on the creative contribution of women artists and designers to the visual arts of Europe and America.

The fully searchable CD-ROM integrates recent sources with four classic, annotated bibliographic works (until now, unavailable in electronic format):

- Chris Petteys' Dictionary of Women Artists: An International Dictionary of Women Artists Born Before 1900. Now out of print, this seminal sourcebook identifies 21,000 women painters, sculptors, printmakers, and illustrators from the Middle Ages to this century.

- Women Artists in the United States: A Selectrive Bibliography and Resource Guide in the Fine and Decorative Arts, 1750-1986 by Paula Chiarmonte. Hailed by Choice as "a fine piece of scholarship," this sourcebook contains nearly 4,000 annotated entries to reference materials on American women artists and art history (including photography, crafts, and folk art).

- Women Artists and Designers in Europe Since 1800: An Annotated Bibliography by Penny McCracken. With material on more than 2,000 individuals in 15 languages, this resource is the first assemblage of its kind in design history (including garden, fashion, and interior designers as well as performance and video art, mixed media, and installation artists).

- Feminist Art Criticism: An Annotated Bibliograplyy by Cassandra Langer. This subjective resource to 1,100 selected works written over the last century about feminist culture, art, theory, and criticism was described by Choice as "a valuable overview of feminist criticism." Reference materials include books, pamphlets, periodicals, catalogs, and newspapers.

0-7838-0090-8 + CD-ROM + $\$ 995$

For product information call: 800/223-1244, Ext. 247 


\section{Science and Technology}

Allison V. Level, associate professor, Southwest Missouri State University, Meyer Library 901 South National, Springfield, MO 65807; allisonlevel@mail.smsu.edu

\section{Slavic and East Europe}

Bradley Schaffner, Russian/Soviet Studies bil)liographer, Watson Library, University of Kansas, Lawrence, KS 66045-2800; bschaffn@ ukans.edu

\section{University Libraries}

Lori A. Goetsch, director of Libraries for Public Services, University of Maryland, 3115
McKeldin Library, College Park, MD 207427011; lgoetsch@deans.umd.edu

\section{Women's Studies}

Daren Callahan, associate professor, Library Affairs, Southern Illinois University, Delyte W. Morris Library, 1803 W. Freeman, Carbondale, IL 62901-2105; dcallaha@lib.siu. edu

\section{Western European Specialists}

Thomas Izbicki, collection development coordinator, Eisenhower Library, Johns Hopkins University, $3400 \mathrm{~N}$. Charles, Baltimore, MD 21218; Izbicki@jhu.edu

\section{("Image is everything" continued from page} 277)

Tired of the image problem? Be part of the image solution. In your next triathlon, wear a T-shirt that says, "Conan the Librarian."

When you accept your Oscar, thank the dean of your library school. And when someone remarks that you don't look like a librarian, take a page from Gloria Steinem and say, "Yes, I do. This is what a librarian looks like."

Maybe once people realize that librarians, like those in most other professions. come in every shape, size, sex, sexual preference, tonsure, decibel level, and hody-fat composition, we'll feel free to just relax and be ourselves. It just so happens that I do wear my hair in a bun. It's great for kickboxing.

\section{("Learning to lead" continued from page 293)}

Recent articles in CERL Neus on ACRL President Maureen Sullivan's theme of "Leadership and Learning" challenge all of us to be both leaders and learners and have offered insights into ways to do so within our libraries today. Another challenge is to stop thinking about learning as something that happens only in a classroom. By participating in various groups and teams doing real work in real time, we can both learn and lead.

\section{Notes}

1. Warren Bennis and Burt Nanus. Leaders: Strategies for Taking Charge (New York: HarperCollins, 1997): 176.

2. Ibid., 17.

3. Peter B. Vaill. Learning as a Way of Being: Strategies for Survival in a World of Permanent White Water (San Francisco: JosseyBass, 1996).

4. Bennis and Nanus, Leaders Strategies, 178-9.

\section{("ULS activities at Midwinter" continued from} page 316)

to validate users' passwords. The user stations are password-protected at night, which effectively limits access to UT students, staff, and faculty. Some universities have adopted open policies toward Web access, while others have initiated strict sign-up policies.

The final topic under discussion .dealt with electronic reference services. Most libraries now offer some type of e-mail reference ser- vice although not all have established procedures for monitoring these services or tracking statistics. The next discussion at the Annual Conference will focus on GIS and data services, planning for science libraries, and 24-hour library access. The Discussion Group welcomes all librarians who are interested in these topics to attend its meeting in New Orleans.-Anne Garrison, reference librarian at Georgia Tech Library, e-mail: anne. garrison@library.gatech.edu 